\title{
Virtual Permanent Establishment: An Approach to the Taxation of Electronic Commerce Transactions
}

\author{
Ángela Carolina VaCa Bohórquez*
}

Contents: I. Introduction. II. Electronic commerce definition. III. Permanent Establishment Principle. 1. Evolution of permanent establishment concept. IV. An approach to the taxation of electronic commerce: Virtual Permanent Establishment. 1. Virtual permanent establishment under the loop of the OECD. 2. The Spanish case. 3. The Indian case. 4. The Colombian case. v. Conclusion. VI. References.

\section{Abstract}

This article approaches to permanent establishment, the rules, and the taxation of electronic commerce transactions as a new "practice" in different countries around the world. The concept invited "to reconsider the "physical presences" as unique way to represent an enterprise.

\section{Introduction}

For over two decades information technology has become an integral part of modern society. Moreover, technology has rapidly invaded everyday life and has brought with it a whole new industry, technological and telecommunication developments, and, most importantly, new ways in which business operates, encouraging globalization and integration of the markets (OECD, Action plan on BEPS, 2013, 7).

In fact, due to the global integration of economies and markets it is possible for corporations that operate all around the world to shift manufacturing bases from high-cost to low-cost locations. Moreover, such enterprises manage risks and of developing by means of global models based on matrix management organizations and integrated supply chains that centralize several functions at a regional or global level. Additionally, globalization has allowed multinational corporations exploit intellectual property at different levels within such organizations (OECD, Action plan on BEPS, 2013,8).

These developments have provided such enterprises with opportunities to significantly minimize their tax burden, taking advantage of the "loopholes" that may arise from the incoherence of the tax rules of ju-

\footnotetext{
* Abogada de la Universidad Externado de Colombia y especialista en Derecho tributario de la misma universidad. Actualmente es candidata a magíster en derecho tributario de la UF Levin College of Law de Nueva York. To cite this article: Vaca, A. (2016). "Virtual Permanent Establishment: An Approach to the Taxation of Electronic Commerce Transactions". Revista de Derecho Fiscal n. ${ }^{\circ}$ 8, Bogotá: Universidad Externado de Colombia. pp. 89-102. DOI: http://dx.doi. org/10.18601/16926722.n8.07
} 
risdictions whose infrastructure is used in the performance of the business activities. For example, in a given state where the residence status for entities is solely determined by the place of incorporation, a foreign company would not be subject to the tax burden provided for a resident entity, even though it has substantial presence; on the other hand, the country of residence might provide with an exemption for the foreign income earned by its residents, which may derive in no taxation of the income derived neither in the source country nor in the residence country.

Thus, Countries have long worked to eliminate such non-taxation in order to minimize trade distortions and obstacles to sustainable economic growth by means of the elaboration of concepts that allow them to tax the revenue produced using their infrastructure and resources, and that cannot be levied under the standards provided in the traditional tax system.

Among such notions, emerges the "permanent establishment" ("PE") concept, which allows a country to tax a foreign person, which notwithstanding is not its resident, has a physical presence in its jurisdiction. These concepts are generally enforced through both bilateral Tax Treaties and domestic legislation. The PE concept was first enshrined in the model tax convention of the League of Nations (1927) and then adopted by the Organization for the Economic Cooperation and Development (“OECD") tax treaty model (1963).

Currently, the PE is understood as the fixed place of business through which the business of an enterprise is wholly or partly carried on (OCDE Model tax Convention on Income and Capital, 2010). However, this concept has experienced a noteworthy dilution during the recent years to meet emerging commercial practices, where physical presence is not required.

So far, although several theories has been formulated to adapt the current definition of permanent establishment to the challenges provided by the electronic commerce, the international organs, such as the Organization for Economic Cooperation and Development ("OECD"), the United Nations ("UN"), the Governmental Authorities and the academia have not reached to a conclusion in the most effective framework to warrant the taxation of such transactions in the Country where economic activities occur and where value is actually generated.

One of the closest approach is the "virtual permanent establishment" theory, which has been discussed by the OECD, the United Nations and the academia, and will be developed in this paper.

\section{Electronic Commerce Definition}

Electronic commerce has been extensively defined. The United States Department of the Treasury describes it as the ability to perform transactions involving the exchange of goods or services between two or more parties using electronic tools and techniques. (Office Tax Policy, U.S.A. Department of Treasury).

For the UN, electronic commerce comprises [c]ommercial activities conducted through an exchange of information generated, stored, [or] communicated by electronic, optic, or analogous means (Rifat Azam, Virginia Journal Of Law \& Technology, 2007).

The Working Party on Indicators for the Information Society of the OECD has defined electronic commerce as "the sale or purchase of goods or services, conducted over 
computer networks by methods specifically designed for the purpose of receiving or placing of orders. The goods or services are ordered by those methods, but the payment and the ultimate delivery of the goods or service do not have to be conducted online. An e-commerce transaction can be between enterprises, households, individuals, governments, and other public or private organizations (OECD Addressing the Tax Challenges of the Digital Economy, 2014).

In summary, the transactions on goods and services using electronic means, at any point, are considered electronic commerce transactions.

In the report on Action 1 ("Tax Challenges of the Digital Economy") of the Base Erosion and Profits Shifting ("BEPS") Action Plan released on September $16^{\text {th }}, 2014$, the OECD summarizes the most common models in which digital businesses (electronic commerce) turn into value, as follows:

- Advertising-based revenues: it includes advertising services that are provided through websites or platforms that offer contents or services for free to potential customers.

- Digital content purchases or rentals: users pay per item downloaded.

- Selling of goods (including virtual items): this model covers online sale of tangible goods and online gaming where users are offered purchasable access to full content or virtual items to enhance the experience.

- Subscription-based revenues, as the agreement of annual payments per license.

- Selling of services: it covers (i) traditional services delivered online such as legal, financial and consultancy services, as well as travel agency and, (ii) a large range of B2B services linked to enterprises who provide core Internet access and act as Internet inter- mediaries (web hosting, domain registration, payment processing, platform access, etc.).

- Licensing content and technology: this category might typically include access to specialist online content (e.g. publications and journals), algorithms, software, cloud based operating systems, etc., or specialist technology such as artificial intelligence systems.

- Selling of user data and customized market research: This category contain Internet service providers (ISPs), data brokers, data analytics firms, telemetric and data gained from non-personal sources.

- "Hidden" fees and loss leaders: This group includes business where profits are derived from online transactions that are connected with physical operations and it is difficult to separate and identify what should be designated as 'online revenue', like online banking, which is offered "free" but is subsidized through other banking operations and fees.

\section{Permanent Establishment Principle}

From the definitions described in section 2 of this document it might be concluded that electronic commerce transactions confront the application of the current international tax regime, since, as described by Azam in E-Commerce Taxation and Cyberspace Law: The Integrative Adaptation Model, it is global, virtual, and anonymous and, and as it increases, the tax challenges become more difficult (Rifat Azam, Virginia Journal Of Law \& Technology, 2007). Indeed, goods and services may be provided with very limited physical presence in a digital environment in any place in the world. Actually, a company can operate without agents, as it can directly contact customers worldwide at 
a reduced cost through Internet. Therefore, the premise of the current PE concept, as the conduct of business through a fixed place in a country is meaningless in electronic commerce transactions. (Rifat Azam, Virginia Journal Of Law \& Technology, 2007, 9).

\section{Evolution of the Permanent Establishment Concept}

As the OECD has stated, the PE concept effectively acts as a threshold which, by measuring the level of economic presence of a foreign enterprise in a given State through objective criteria, determines the circumstances in which the foreign enterprise can be considered sufficiently integrated into the economy of a state to justify taxation in that state (Holmes, 2007; Rohatgi, 2005).

The first approach to the PE concept dates back to 1899, when Austria-Hungary and Prusia signed a tax treaty, which required a fixed place of business for the taxpayer to be liable in the source country. Then, in 1927, it was enshrined in the model tax convention of the League of Nations (1927) and the modern notion was adopted by the Organization for the Economic Cooperation and Development (“OECD”) tax treaty model (1963) (Arvid A. Skaar,).

In the modern PE definition the key issue is the fixed physical presence in the source country, because in such a case, this jurisdiction is entitled to tax profits resulting from the development of activities within its territory as long as such profits can be attributed to the PE; and the residence country agrees to grant either a tax credit or a tax exemption for the amount of taxes paid to the source country in order to eliminate double taxation. Though, the current definition of PE contained in the OECD Model Tax
Convention was extended in order to include certain activities which did not fit in such notion, but as per their nature resulted in the regular performance of business within the source country territory, such as dependent agents who are entitled to conclude contracts in source countries and construction projects lasting more than 6 or 12 months. (Cockfield, 2003) Hence, the PE concept requires (i) a sufficient level of economic presence, directly or through third parties, (ii) obtaining revenues and (iii) the existence of a nexus between the economic presence and the income.

However, with the expansion of the internet, digital economy increasingly grew up and the definition of PE required to be reappraised to cover situations in which some enterprises were developing dematerialized digital activities, where no physical presence is required. Thus, the Government of the United States initiated the discussion in 1996, when the Treasury Department issued a report with the purpose of framing the policy challenges proposed by the electronic commerce. In turn, in 1998 the Canadian government issued two reports suggesting that a server might constitute a PE taking into account certain circumstances (Cockfield, 2003, 408).

As far as the OECD is concerned, the steps in reinterpreting the $\mathrm{PE}$ notion started in 1998 at the Ottawa Ministerial Conference on Electronic Commerce, where the member countries reached to an agreement regarding the principles that should guide the development of rules in international tax matters for the electronic commerce. (Cockfield, 2003, 408). Such principles are as follows:

Neutrality: According to this principle, tax rules applicable to electronic commerce and conventional commerce should be neutral and the taxpayers in alike situations perform- 
ing comparable transactions should be taxed in similar ways.

Efficiency: Costs for both the taxpayers and the tax authorities should be diminished as far as possible.

Certainty and Simplicity: The tax rules should be clear and simple to understand in order for the taxpayers to anticipate the tax consequences in advance of a transaction.

Effectiveness and Fairness: The tax liability should be fair and accrued in the proper time and the potential tax avoidance should be reduced while keeping neutralizing measures proportionate to the risks involved.

Flexibility: The tax rules should be flexible and dynamic to follow technological and commercial developments.

Taking into account these principles and the rapidly expansion of the electronic commerce, in 2003 the OECD included in the Commentary on Article 5 of the OECD Model Tax Convention the possibility to treat servers as PEs, rather than web pages, as long as substantial activities are perform through them.

In fact, according to paragraph 42.2 of the Commentary on Article 5 of the OECD Model Tax Convention, a web page cannot be considered as a "fixed place of business" because as per its nature (it is a combination of software and data), it is not a physical asset that has the capacity to link an enterprise to a specific location. The agreement signed with the Internet Services Provider (ISP) to host a webpage in his server does not indicate that the server is a location being at the disposal of the enterprise, even if the location of the server is known.

However, a server might constitute a PE, if it is an essential and significant part of the business activity of the enterprise as a whole, or where other core functions of the enterprise are carried on through the computer equipment. (Rifat Azam, en Virginia Journal Of Law \& Technology. University Of Virginia, 2007, 12) But, if the server displays a web page, takes a customer's order, processes payment and transmits a digital good or service to the end consumer (Cockfield, 2003, 409), it would not be deemed as a PE.

Several authors have criticized this new category of $\mathrm{PE}$, since it is inaccurate in linking a geographical place with activities that produce income and it is easy to manipulate. For example, Azam has stated that the territorial location of the server is a highly irrelevant and mobile factor and one that cannot lead to well-established taxation of e- commerce income (Rifat Azam, en Virginia Journal Of Law \& Technology, 13), because often there is no real economic allegiance between the place of the server and the production of the income. Also, [t]he large number of examples given with many technical and specific details cannot be used as a guiding and useful working tool for tax authorities or for the international business community (Rifat Azam, Virginia Journal Of Law \& Technology, 2007, 13).

Cockfield has argued "that servers should never constitute PEs, mainly as a result of the fact that the location of a server need not have any geographic connection to activities that add value and create income. Servers and the software functions within a server form part of the hardware and software infrastructure of the Internet and can be shifted outside of the country where an e commerce firm is based or where software products are developed, as well as outside of the source country where e-commerce goods and services are purchased" (Cockfield, 2003, 409). 
Alexandra Bal sustained that " $[\mathrm{t}]$ he current $\mathrm{PE}$ definition cannot capture and tax business profits generated by non-residents conducting business via digital technology. The result is that cloud providers can easily avoid source taxation in countries where their customers are located and where they receive income from" (Bal, 2014).

As Cookfield has said, "[t]wo main deficiencies of the new rule have been identified: (a) server/PEs will not effectively allocate taxing jurisdiction and revenues to source countries, and (b) server/ PEs offer tax planning opportunities for multinational enterprises to shift income outside of residence countries". In fact, the OECD has recently reached to the same conclusion and thus, this is one of the main issues addressed in the BEPS Action Plan.

Conversely, the UN model tax treaty has a broader definition of PE, including a "restricted force of attraction", under which a state where nonresidents maintain traditional PEs are entitled to tax other income that is attracted to the PE, despite this income is not directly attributed to the PE (Cockfield, 2003, 409).

\section{IV.An Approach to the Taxation of Electronic Commerce: Virtual Permanent Establishment}

As it is well known, Multinational Enterprises have exploited their digital presence to obtain significant income from different countries with low taxes, and in most of the cases without paying taxes. Thus, it has led to proposals to redefine the PE concept.

One proposal is the creation of the "virtual permanent establishment" to the current understanding (definition) of PE. Luc Hinnekens, author of this theory, proposed that the taxing nexus for electronic commerce should be "the continuous commercially significant conduit of business activity", rather than the fixed place of business. The virtual PE approach applies to the jurisdictional criterion for source-based taxation of profits (Hinneckens, 1998, 195).

Furthermore, Hinnekens states that the modern PE definition should be "re-invented" in order to apply to electronic commerce the original idea of taxation on basis of economic allegiance and equivalence and establish common thresholds for differentiating commercial mainstream from auxiliary business activity. For such purpose, Hinnekens suggested (i) to extend the PE definition of Art. 5 of the OECD Model Tax Convention and (ii) to introduce a special article in the existing treaties allocating the right to tax profits from business over the Internet to their source state even in the absence of PE, much in the same manner as Art. 17 now provides for the taxation of artistes and sportsmen who may not maintain a permanent establishment anywhere in the state as long as they exercise their activity on its territory (Hinneckens, 1998, 195).

Additionally, in order to determine if the taxing nexus is met, Hinnekes proposes the development of a qualitative and quantitative facts and circumstances test, taking into account issues like the turnover or number of transactions. Indeed, the author takes as basis for the development of this test the one employed by the United States courts in the context of state and local sales and use taxes.

Essentially, the aim of such test is to prevent the States to levy out-of-state businesses and collect sales taxes on purchases by residents of the taxing state disowning the provisions of the Federal Constitution for state and local sales and use taxes pur- 
poses. Under this test, the Supreme Court determines whether sub-federal laws that regulate local sales and use taxes (45 states and over 7,000 local governments) met the constitutional requirements based on a "Due Process" nexus (Hinneckens, 1998, 197). According to the rulings of the Supreme Court, specifically in Quill Corp v. North Dakota (Quill Corp v North Dakota, 1992), there will be a Due Process nexus when (i) the seller develops activities that are "sufficiently and purposefully aimed at residents of the taxing state" and, therefore, derives benefits from the market of such state: (ii) the taxpayer's conduct and operations in the taxing State rise to a level where it should have reasonably anticipated being towed into court there; and, (iii) the seller's activities in the taxing state are continuous and constitutes a significant part of its general business in there (Hinneckens, 1998, 198).

Moreover, it is necessary to determine the profits that are attributable to the "virtual PE. For Hinnekens, the current redaction of Article 7 of the OECD Model Convention does not provide with a proper allocation of electronic commerce profits, since it is difficult to find a comparable and to apply the transactional test due to the close vertical integration of the business. The method used in each case must be determined according to the particular features of the business.

As Hennikens asserted, the "virtual PE" approach (i) is relatively and competitively neutral to the buyer or user in the market, since source taxation of its profit is probably more neutral than taxation exclusively based on residence, (ii) it recognizes extensive source taxability according to economic allegiance and subject to thresholds, (iii) it is effective because it establishes a link between the electronic business and its customer established in the source country(Hinneckens, 1998, 199).

The "virtual PE" has its weaknesses. Hinnekens recognizes that as it reinvents the taxing nexus and requires a different approach for the determination of attributable profits, extra uncertainties might be risen. Thus, case law, administrative practice, guidelines and bench marks developed by the OECD Committee of Fiscal Affairs are necessary (Hinneckens, 1998, 199).

Other authors has criticized the viability of this proposal. Cockfield has pointed out that a qualitative economic presence test is not efficient as the constitution of a "virtual PE" implies the compliance of onerous obligations for enterprises that are not certain they should comply with. Furthermore, it might be difficult to enforce such liabilities, since there is no an international tax authority in charge to do so. In addition, Cockfield highlights that:

tax authorities and courts throughout the world will develop their own interpretation of the factors that meet the requirements for domestic source taxation. Capital importing nations will tend to interpret the factors broadly to permit their tax authorities to exert jurisdiction over nonresident firms, while capital exporting nations will tend to construe the test in a more narrow fashion. (Cockfield, 2003, 417).

Kim David Lexner argues that that this theory requires, as the "fixed place of business" do, some kind of physical presence by the vendor, before he is taxed, because "you can neither have operations, nor systematic 
activities, within a state, without you or your employees or agents being present in that state (Lexner, 2010).

Likewise, Walter Hellerstein sustained that "the problem with this suggestion, of course, is the enforceability of this standard from a practical standpoint, even though enforcement jurisdiction exists as a matter of law under a virtual PE standard. Indeed, these practical enforcement issues are the ultimate arbiters of our ability to align substantive and enforcement jurisdiction when substantive jurisdiction is defined to include values associated with a digital presence. (Hellerstein, 2014).

\section{Virtual Permanent Establishment under the Loop of the OECD}

The OECD has worked for more than 20 years analyzing the impact of the electronic commerce to the current international tax legislation. As mentioned before, in 1998 the principles that should guide the development of rules in international tax matters for the electronic commerce were established.

In 2005, the OECD released the report titled "Are the Current Treaty Rules for Taxing Business Profits Appropriate for E-Commerce?", based on the work of the business profit Technical Advisory Group (“BP TAG”). In such report, the OECD, studied the "virtual PE" theory as an alternative nexus that would apply to electronic commerce operations.

According to such report, the PE definition requires to be extended in three ways in order to extend the PE definition, as follows (OECD, 2005, 67):

(i) A so-called "virtual fixed place of business" through which the enterprise carries on business (i.e. an electronic equivalent of the traditional permanent establishment). In other words, when the enterprise maintains a web site on a server of another enterprise located in a jurisdiction and carries on business through that web site, a PE is configured and the place of business is the web site, which is virtual.

(ii) A so-called "virtual agency" (i.e. an electronic equivalent of the dependent agent permanent establishment). This concept would be an electronic equivalent of a dependent agent and, therefore, will cover situations where contracts are habitually concluded on behalf of the enterprise with persons located in the jurisdiction through technological means rather than through a person.

(iii) A so-called "on-site business presence", which would be defined to include "virtual" presence. An enterprise providing on-site services or other business interface (which could be a computer or phone interaction) to users located in certain Country may be deemed as "on-site business presence". Under this alternative, it would be necessary to specify a minimum threshold to ensure that source country taxation would only be applied where there is a significant level of economic activity. Possible thresholds might include a minimum time during which the enterprise regularly operates within the jurisdiction, or monetary thresholds, or limitations on the types of activities covered (e.g. exclusions for preparatory or auxiliary activities, or intermittent and occasional activities).

In the report, the OECD indicates that the adoption of this approach would ineludible imply the reconsideration of the current rules regarding the attribution of profits and a significant reinterpretation of the arm's length principle "in order to introduce the notion of virtual functions, use of virtual as- 
sets and virtual risk assumption, beyond the possible recasting suggested for the virtual agent alternative".

The OECD concluded that it would not be appropriate to dramatically change the PE concept to include such notions, since

[e]lectronic commerce and other business models resulting from new communication technologies were not perceived by the BP TAG to justify, by themselves, a dramatic departure from the current rules. There did not seem to be actual evidence that the communications efficiencies of the Internet had caused any significant decrease to the tax revenues of capital importing countries (OECD, 2005, 168).

In the context of the discussion regarding the BEPS Action 1: "Address the Tax Challenges of the Digital Economy", the OECD mentioned the Virtual PE theory as an alternative examined in 2005 in order to adapt the current international tax policies to the digital economy, but did not pronounce a word on the viability of the alternative under the current scenario.

\section{The Spanish Case}

On March 15 ${ }^{\text {th }}, 2012$, the Tribunal Economico Administrativo Central of Spain issued Ruling R.G. 2107-07, deciding whether the sale of goods in Spain by Dell Products Limited ("DLP"), an entity with residence in Ireland, triggered a PE or not. This "Tribunal" is an administrative body, rather than a judicial entity, since it is part of the Ministry of Treasury of Spain.

The complex business operation structure of DLP in Spain involved sales through its subsidiary in Spain (who acted as a com- missionaire agent) to specific customers and through its web page to other customers (ecommerce activities).

For the performance of the e-commerce activities, DLP had at its disposal one employee of its Spanish subsidiary who was in charge of adjusting the content of the web page to the Spanish market, but the web page was hosted on servers located outside Spain.

The Spanish Tax Administrative Tribunal held that DPL's e-commerce activities constituted a PE in Spain based on the virtual permanent establishment theory. This entity reach to such conclusion based on the following arguments: (i) notwithstanding the web page itself does not configure a PE according to paragraph 42.2 of the Commentaries to the OECD Model Tax Convention, the fact that one of DPL's subsidiary's employee, who is based in Spain, is in charge of the administration of the web page means that the company has physical presence in such country. To stress this argument, the Tribunal sustains that, although under the Commentaries to the OECD Model Tax Convention the configuration of a PE in e-commerce transactions is determined by the presence of a server where the web page is hosted, Spain has expressed that it has reserves in the application of this provisions; (ii) the web page is indistinctly used by both DPL and the Spanish Subsidiary and it is addressed to the Spanish market in general, without bringing the customers with the possibility to identify the entity which they are dealing with. Additionally, the Spanish Subsidiary is the owner of the ".es" domain and from the transfer pricing report it was identified that it performs a large number of transactions through the website.

Finally, the Tribunal ruled that the profits that are attributable to the Spanish PE and, 
thus, would be taxable in Spain are the proceeds earned in the sale of products to the Spanish Market. For Sprague, "[t]he effect of that approach to PE profit attribution is that all net income derived from the relevant market in the books of the principal would be allocable to the PE, assuming that $100 \%$ of the allocable expenses incurred by the principal were treated as deductible expenses of the PE. This approach clearly is not consistent with the authorized OECD approach of conceptualizing the PE as a separate and distinct enterprise from the head office, and determining the profits attributable to the PE by reference to deemed transactions between the PE and the head office (Sprage in International Journal, 2013).

From the above mentioned it is clear that this Ruling reopened the discussion around the applicability of the Virtual PE theory and it constitutes a relevant precedent to the extent that Spain is a member of the OECD, entity that has been reluctant to apply this theory and redefine the PE concept. Nevertheless, it is worth mentioning that this resolution was subject to appeal before the Audiencia Nacional (Spanish Tax Court) and therefore it is pending for its definitive application.

\section{The Indian Case}

Indian judges have advanced in the conceptualization of the configuration of a PE under a virtual environment. During the last 8 years, the Indian Courts have gave important steps ahead to redefine the PE concept to cover electronic commerce transactions.

For example, in the Morgan Stanley ruling (2007), the Supreme Court made a reference to a "software PE", but did not define such notion. The Madras High Court in the case of Verizon Communications Singapore Ltd while deciding whether payments made to Verizon Singapore from India resulted in royalty income, stated that physical presence of an entity had become insignificant in a virtual world (Butani \& Jain in IBDF Asia-Pacific Bulletin, 2014, 251). In this case, the Court ruled that in determining if a foreign company has a virtual presence and, in consequence, a PE in India, the following aspects are to be examined: presence of equipment, rights and the responsibility of the foreign entity vis-à-vis its customer.

An important advance is present in Galileo International Inc and Maruthi Info. and Tech Centre case. In this opportunity, the Indian Income Tax Appellate Tribunal held that a PE was configured in India because (i) existed a business connection of Galileo in India due to the fact that the Company provided equipment, connectivity and configuration through a continuous, process available to travel agents in India; (ii) there was a fixed place of business, since part of the reservation services performed with Galileo's system took place in the premises of the clients where the computers were placed; and (iii) Interglobe constituted a dependent agent PE for Galileo in India, as it was functionally and financially dependent on the company. No attributions of profits was required, since the Court found that it was an arm's length transaction (Butani \& Jain in IBDF AsiaPacific Bulletin, 2014, 251)..

Regarding the configuration of a PE because of the virtual presence through a web page in India (Contrary to the position of the OECD, India has sustained that a website is capable to constitute a PE in certain circumstances ), the Indian Income Tax Appellate Tribunal held in the Right Florists Pvt Ltd. case that the presence of search engines of 
Google and Yahoo through websites, when servers are located outside India did not constitute a business connection or PE in India (Butani \& Jain in IBDF Asia-Pacific Bulletin, 2014,251), because "a search engine having its presence through a website cannot create a fixed place (basic rule) for PE purposes, unless web servers are located in the relevant jurisdiction".

\section{The Colombian Case}

As a developing country that has opened its markets to the foreign inversion just in the 1990s, electronic commerce in the Colombian economy is incipient and, thus, current tax legislation on electronic commerce transactions has not been developed as it would be desired.

Also, Colombia is relatively new in the Tax Treaties world. The first treaty that Colombia signed with the purpose of avoiding the double taxation is the Andean Pact, which has been in force as of 1971 .

The Andean Pact Treaty (which most recent version is Decision 578 of 2004) was part of a plan to strengthen the economic relationships with Ecuador, Peru, Bolivia and formerly Venezuela in the context of protectionist policies and industrialization projects. Thus, this Treaty is based on the source principle and it does not currently provide with a PE disposition.

It was only until 2008 when the first Tax Treaty based on the OECD model (residence principle) entered into force in Colombia (the Tax Treaty signed with Spain) and, therefore, provided with a PE disposition. In 2005, Colombia signed the first Tax Treaty based on the OECD model with Spain. This treated entered into effect as of October $23^{\text {rd }}$ 2008.
Having in mind the above mentioned and that Colombia has only 7 Tax Treaties in force (with Spain, Chile, Switzerland, Canada, Mexico, India and Korea). Moreover, the domestic legislation adopted the PE concept in 2012, following the OECD recommendations. This disposition was enacted in 2013 and reproduces the provision of the OECD Tax Convention Model and its comments. The current legislation, case law and Tax Authorities rulings have not developed the scope of the PE concept when it comes to an electronic commerce transaction between a Colombian resident and a Tax Treaty Country resident as it would be desired.

The closest approach came in 2013, when the Tax Authorities issued Ruling No 73092 regarding the configuration of a $\mathrm{PE}$ in $\mathrm{Co}-$ lombia for a Swiss company that would provide English courses abroad through Internet using a digital platform located in Brazil to a governmental entity's employees (the Tax Authorities themselves). In this case, the Tax Authorities concluded that the Swiss Company had a permanent establishment under the provisions of the Tax Treaty signed with Switzerland.

However, the Tax Authorities reached this conclusion because there was a dependent agent in Colombia. In fact, the Tax Authorities did not even analyze whether the provision of English courses through internet would trigger a PE in Colombia or not. They focused the analysis on the fact that a Colombian subsidiary of the Swiss Company was authorized to negotiate and conclude the contract on behalf of the Swiss Company.

In the context of electronic commerce transactions such as hosting services and access to data bases, performed by persons that are not residents in a Tax Treaty jurisdiction, the Colombian Tax Authorities have ruled 
that the income is not considered as Colombian sourced since they are not provided in Colombia (Ruling 74171 of 2005). Moreover in Ruling $\mathrm{N}^{\circ} 6256$ of 2005, the Tax Authorities held that electronic commerce transactions performed by nonresidents are not levied with income tax in Colombia.

Conversely, according to the hold in Rulings 74171 of 2005 and 37529 of 2002, the proceeds of intellectual property license granted through internet, as software and music, will be taxed in Colombia to the extent that domestic legislation provides that granting licenses of intellectual property to Colombian residents is considered as provision of services within Colombian territory.

From the above mentioned precedents, it is clear that the Tax Authorities have not focused their attention to the potential base erosion, and particularly to the absence of taxation, that would be led by transnational inbound electronic commerce transactions that involve the Country. For electronic commerce transactions performed by Colombian residents, current legislations require the taxpayers to report to the Tax Authorities the operations performed.

Thus, the active participation of Colombia in the discussion of the BEPS action plan would be an excellent opportunity to recognize the current loopholes and legislative weakness in the regulation of electronic commerce taxation.

\section{Conclusion}

It is not a secret that information technology has brought with new ways in which business operates, encouraging globalization and integration of the markets, which has made it possible for multinational entities to shift manufacturing bases from high-cost to low-cost locations and managing risks and of developing, provided with opportunities to impressively minimize their tax burden.

This is due to two important factors: (i) the existing ambiguities of the tax rules of the countries that may be involved in electronic commerce transaction (source and residence states) and, (ii) the dilution of important notions that were constructed in the international field to harmonize the different domestic rules under the digital environment, where physical presence is not required.

The "virtual permanent establishment" theory was proposed by Luc Hinneckens to reconsider the "physical presences" as unique nexus of an enterprise with the source country by providing as an additional nexus "the continuous commercially significant conduit of business activity".

However, this proposal has been strongly criticized, since its adoption might require (i) a complete redefinition of the current PE and attribution of profit rules, besides the (i) compliance of formal obligations by the multinational enterprises in every country where they have costumers, that might be difficult to satisfy and enforce.

In fact, in the "Are the Current Treaty Rules for Taxing Business Profits Appropriate for E-Commerce?" report (2005) the OECD held that such a dramatic changes in the international taxation rules are not required. Moreover, although the OECD accepted that it is required to address the challenges of the digital economy, this organization did not even discuss the virtual PE theory in the "Addressing the Tax Challenges of the Digital Economy" report, released on September $16^{\text {th }}, 2014$ in the context of the action plan to address the Base Erosion and Profit Shifting ("BEPS").

The above mentioned shows that the PE definition will only be re-conceptualized 
when both capital exporting and capital importing countries reach to an agreement in the best alternative to tax electronic commerce transactions and what is the best means to enforce it, taking into account the neutrality and equity principles. In other words, the current international tax law will be dramatically changed when capital exporting countries would stop fearing that their multinational entities are going to be affected by the imposition of taxes on capital importing countries.

In the specific case of Colombia, the work has not yet started. First, as Colombia is not an OECD member country, the modification of the current PE definition shall be made through the modification of the existing Tax treaties and amending the domestic legislation.

Notwithstanding the Colombian Tax Authorities are actively participating in the discussion of the BEPS action plan, our legislation is still emerging when it comes to international electronic commerce transactions and the Tax Authorities are not prepared to adopt dynamic rules that allow them to reduce the tax evasion and warrant a proper environment to foreign investors. Furthermore, the PE definition is relatively new and has not been developed taking into account the needs of the Country. In fact, their opinions look shy and they are limited to reproduce the OECD tax treaty model and its commentaries.

The Colombian Tax Authorities should review the current standard notions and guidelines provided by the OECD and analyze how it would impact the national market, especially the small and medium size companies that are the principal actors of the Colombian economy, since they might borne a higher tax burden that the multinational enterprises, which in most of the cases are better prepared to affront this challenges.

Also, the Colombian Tax Authorities should create a "test" or parameter to determine the cases in which it might be considered that the infrastructure of the country is used in an electronic commerce operation, for example, taking into account the final destination of the goods or the final beneficiary of the services; issues that, as been discussed in this paper are critical to establish.

Thus, I consider the participation of Colombia in the BEPS Action Plan forum as a starting point in the understanding of the performance of the Country in the global market from a tax standpoint. However, I consider that the modification of the PE definition in the current scenario would not be as successful as it would be desired, since the legislators and Tax Authorities are not completely aware of the implications that may arise.

\section{References}

OECD Model Tax Convention on Income and on Capital. Condensed Version Article 7. July 22 of 2010.

Office of Tax Policy, United States Department of the Treasury, Selected Tax Policy Implications Of Global Electronic Commerce 22. Http://www.treas.gov/offices/tax- policy/library/internet.pdf.

Rifat Azam, E-Commerce Taxation and Cyberspace Law: The Integrative Adaptation Model. Virginia Journal Of Law \& Technology. University Of Virginia Vol. 12, No. 5. 
Arthur J. Cockfield, "Reforming the Permanent Establishment Principle through a Quantitative Economic Presence Test”. 38 Can. Bus. L.J. 2003.

Alexsandra Bal, The Sky's the Limit - Cloud-Based Services in an International Perspective. IBDF Bulletin for International Taxation, September 2014.

Luc Hinneckens, Looking for an Appropriate Jurisdictional Framework for Source-State Taxation of International Electronic Commerce in the Twenty-first Century (1998). Intertax 192.

Kim David Lexner, Selected Issues in the U.S.-Dk Tax Treaty: Permanent Establishment in relation to E-Commerce Transactions and the distinction between payment for services and payment for intangible property rights. CORIT Discussion Paper N. 7 2010. Gary D. Sprague, Spanish Court Imposes Tax Nexus by Finding a "Virtual PE". International Journal. http://www.bna.com/spanish-court-imposes-n17179871765.

Mukesh Butani and Parul Jain, Permanent Establishment Concept - An Indian Perspective (2014). IBDF, AsiaPacific Bulletin. 